\title{
Menelusuri Sosok Kartini Melalui Liniearitas Alur Naratif Propp Dalam Novel Biografi Karya Pram
}

\author{
Regina Caeli Cahaya Tarsisty \\ Program Studi Ilmu Komunikasi, Universitas Bunda Mulia, Jakarta, Indonesia. \\ Email: regina.caeli25@gmail.com
}

Rustono Farady Marta

Program Studi Magister Ilmu Komunikasi, Universitas Bunda Mulia, Jakarta, Indonesia. Email:marta@bundamulia.ac.id

(corresponding author)

\section{Joshua Fernando}

Program Studi Ilmu Komunikasi, Universitas Mpu Tantular, Jakarta, Indonesia.

Email:joshuafernandosaty@gmail.com

\section{Article Info}

Article History

Received 21 Feb 2021

Revised 19 Apr 2021

Accepted 26 Apr 2021

\begin{abstract}
Gender discrimination in Indonesia has existed since ancient times. As a Javanese woman, Kartini became a figure who experienced the past and even by her family. Due to her limitations, Kartini wrote about her restlessness and thoughts in the form of letters sent to her Dutch friends. The letters were then collected and put together into a book entitled Door Duisternis tot Licht. Pramoedya took some fragments of Kartini's letter, and tried to see Kartini in her literary glasses in the biographical novel Call Me Kartini Saja. Relying on qualitative methods and constructivist paradigms and using Vladimir Propp's narrative analysis, the purpose of this research is to reveal the description of the character's function in the narrative in the novel. The role analysis is only in narratives that contain elements of feminism. This research found that the novel P Call Me Kartini Saja contains seven of the 31 narrative functions and seven characters which are grouped into four character functions. Through the narrative function and character function that have been analyzed in this novel, this suggestion suggests that Kartini's spirit in fighting for emancipation through her writing and thoughts should always be lived out in her daily activities because her struggle allowed Indonesian women to indulge their rights.
\end{abstract}

Keywords: liniearity, kartini, woman emancipation, gender roles, vladimir propp's narrative analysis

\begin{abstract}
Abstrak: Diskriminasi gender di Indonesia sudah ada sejak zaman dahulu. Sebagai perempuan Jawa, Kartini menjadi sosok yang mengalami diskriminasi tersebut dan bahkan oleh keluarganya. Karena keterbatasannya, Kartini menulis kegelisahan dan pemikiranpemikirannya dalam bentuk surat-surat yang dikirimkan ke teman Belandanya. Surat-suratnya tersebut kemudian dikumpulkan dan dijadikan satu ke dalam buku berjudul "Door Duisternis tot Licht". Pramoedya mengambil beberapa penggal surat Kartini, dan mencoba
\end{abstract}


melihat Kartini dalam kaca mata sastranya dalam novel biografi Panggil Aku Kartini Saja. Bersandar pada metode kualitatif dan paradigma konstruktivis serta menggunakan analisis naratif Vladimir Propp, tujuan penelitian ini adalah mengungkap gambaran fungsi karakter pada narasi dalam novel. Analisis dibatasi hanya pada narasinarasi yang mengandung unsur feminisme. Penelitian ini menemukan bahwa novel Panggil Aku Kartini Saja mengandung tujuh dari 31 fungsi narasi dan tujuh karakter yang dikelompokkan ke dalam empat fungsi karakter. Melalui fungsi naratif dan fungsi karakter yang sudah dianalisis dalam novel ini, penelitian ini menyarankan bahwa semangat Kartini dalam memperjuangkan emansipasi melalui tulisan dan pemikirannya harus selalu dihidupi dalam kegiatan sehari-hari karena perjuangannya membuat perempuan Indonesia dapat menikmati hakhaknya secara lebih baik.

Kata kunci: liniearitas, kartini, emansipasi wanita, peran gender, analisis naratif vladimir propp

\section{PENDAHULUAN}

Hingga saat ini, kedudukan kaum perempuan dalam masyarakat masih berada di bawah kekuasaan laki-laki. Ini bertentangan dengan kodrat manusia karena manusia pada dasarnya dilahirkan setara (Sumar, 2015: 159).

Peran gender merupakan tanggung jawab yang diperankan oleh laki-laki ataupun perempuan berdasarkan kebudayaan yang berlaku di masyarakat serta dalam kehidupan sosial (Rajab, 2018). Peran gender karenanya dapat dipahami sebagai hasil kehidupan sosial yang berlaku di masyarakat pada golongan tertentu, dan pada akhirnya dijadikan sebagai budaya yang berlaku di masyrakat tersebut (Sari, 2014).

Menurut You et al, (2019), dominasi yang terjadi antara laki-laki atas perempuan merupakan salah satu dasar kekerasan simbolik, yang merupakan bentuk kekerasan yang cenderung halus dan tidak terlihat, bahkan banyak yang tidak disadari. Wacana Patriarki merupakan kekerasan karena secara tidak langsung menjebak kaum perempuan dengan menentukan cara pandang, pola pikir, cara merasa dan bertindak. Masyarakat juga mengadopsi normanorma budaya patriarki dalam setiap aspek kehidupan. Maka dari itu, sistem patriarki telah menjadi suatu kewajaran dan biasa berlaku di masyarakat. Patriarki juga mengartikan adanya "kekuasaan ayah”, dalam hal ini keberadaan laki-laki yang lebih dominan daripada kaum perempuan (Novarisa, 2019:196).

Mulyadi (2018) menyatakan bahwa budaya patriarki terlalu berfokus dan membesar- besarkan perbedaan biologis yang terdapat pada laki-laki dengan perempuan, serta memastikan bahwa lakilaki menempati peran maskulin atau dominan dan perempuan menempati posisi feminin dan subordinat (Sakina \& Siti, 2017: 72).

Dominasi laki-laki dalam kehidupan sosial menandakan bahwa budaya patriarki masih berlaku di masyarakat tersebut seperti Indonesia (Omara, 2004: 149). Dominasi laki-laki atas perempuan sudah berlangsung lama. Pada zaman dulu, perempuan-perempuan Indonesia tidak diperkenankan untuk 
menikmati bangku pendidikan kecuali perempuan tersebut berdarah bangsawan (Septiani, 2017: 105). Itupun juga terbatas dibandingkan laki-laki.

Selain tidak diperbolehkan mengenyam pendidikan, mereka juga tidak diperkenankan ikut ambil bagian dalam pekerjaan-pekerjaan yang berada di luar rumah. Ini terjadi terutama, misalnya, pada Raden Adjeng Kartini. Sosok yang kemudian dikenal sebagai tokoh wanita yang berjuang untuk menyuarakan kebebasan dan hak perempuan di Indonesia (Sakina \& Siti, 2017: 72).

Perempuan yang berasal dari Jepara ini menjadi tokoh yang menyuarakan kesetaraan gender di Indonesia. Raden Ayu Kartini (atau yang bisanya dikenal sebagai Raden Adjeng Kartini, RA Kartini) mendambakan adanya kesetaraan hak dan kewajiban antara laki-laki dan perempuan.

Meskipun RA Kartini lahir sebagai anak seorang Bupati Jepara, tapi lahir dari garwa selir. Ibu Kartini sendiri berasal dari rakyat biasa. Hidup di bawah feodalisme, membuat Kartini menjadi sosok perempuan yang kuat dan kritis (Mustikawati, 2015: 66).

Bagi Kartini, hak mendapatkan pendidikan tidak hanya berbatas pada jenis kelamin karena pendidikan mengenai budi dan jiwa (Muthoifin et al., 2017: 37). Di sisi lain, ia juga menyadari keterbatasannya karena tidak memiliki hak yang besar untuk bersuara, bahkan kepada ayahnya sendiri. Agar bisa berpendapat, bersuara, dan bahkan berteriak maka Kartini menulis. Ia menulis beratus-ratus surat yang ia tujukan kepada sahabat- sahabatnya di Belanda, berisikan tentang hal-hal yang dilihat maupun dirasakannya.

Surat-surat tersebut pada akhirnya dirangkum menjadi sebuah buku yang dikenal dengan judul "Habis Gelap Terbitlah Terang" ("Door Duisternis tot Licht”) ditulis dengan menggunakan bahasa Belanda. Adapun kumpulan surat tersebut berisikan perjuangan wanita untuk dapat hidup bebas dari kungkungan adat-istiadat yang berlaku di masyarakat, serta tentang pemikiran Kartini mengenai kebebasan (Rahayu \& Aprilia, 2018: 4). Surat-surat ini kemudian dipotong dan dirangkai menjadi beberapa bagian oleh Pramoedya Ananta Toer. Lalu, ditambahkan beberapa penjelasan yang menarik menjadi sebuah novel biografi dengan judul Panggil Aku Kartini Saja (Masofa, 2018: 2).

Narasi yang terdapat dalam novel biografi ini tidak hanya menggambarkan isi dari cerita yang dibawa, tapi juga menggambarkan karakter- karakter yang terdapat dalam cerita tersebut. Adanya karakter membuat penulis dapat leluasa menuangkan maksud gagasannya. Mauli \& Badruzzaman (2020) juga menyebutkan bahwa setiap narasi memiliki dua bagian: yang pertama sebuah cerita, isi atau rangkaian peristiwa (tindakan, kejadian), ditambah dengan apa yang disebut dengan eksisten (karakter). 


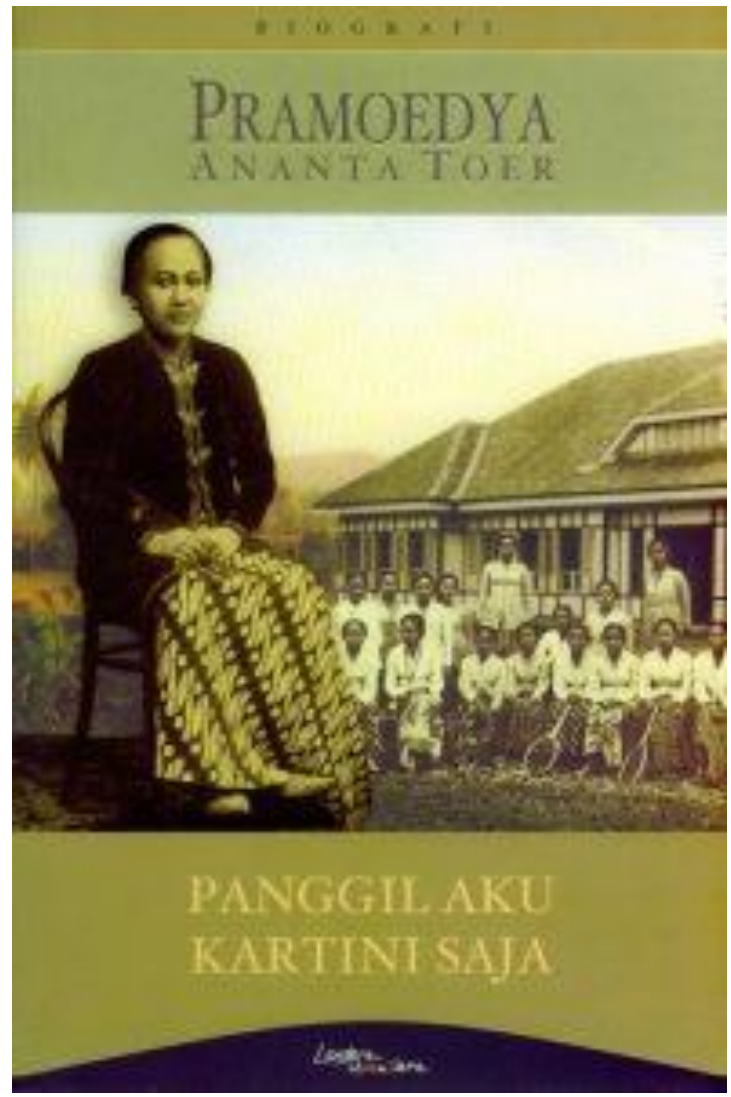

Gambar 1. Novel Biografi Panggil Aku Kartini Saja

Novel biografi Panggil Aku Kartini Saja karya Pram ini tidak hanyak menjelaskan cerita, tapi mendudukkan karakter-karakter yang terlibat di lingkungan Kartini semasa hidupnya. Karya Pram ini juga menjadi begitu penting karena Pram membaca ulang konteks zaman, pergulatan pemikiran, dan juga tindakan Kartini semasa hidupnya. Selain itu, dalam novel ini, Pram juga menuliskan kutipan-kutipan suratmenyurat kepada sahabat-sahabat Belandanya dan juga memasukkan pemikirannya terhadap tulisan-tulisan Kartini.

Feminisme merupakan gerakan yang dilakukan untuk mengakhiri diskriminasi seks, ekploitasi yang didasari seks, dan tindakan yang dilakukan untuk merendahkan seks itu sendiri (Gumelar \& Mukhroman, 2015: 73). Teori feminisme menjelaskan kehidupan sosial dan pengalaman manusia dilihat dari perspektif perempuan. Pertama, teori ini memusatkan perhatiannya pada situasi dan pengalaman wanita dalam hidup bermasyarkat. Kedua, teori feminisme menempatkan wanita sebagai objek kajiannya. Ketiga, teori ini aktif membela wanita serta berusaha menghasilkan dunia yang lebih baik secara khusus bagi wanita dan manusia pada umumnya (Aliyah et al., 2018).

Feminisme liberal muncul sejak abad ke-18. Berakar dari pemikiran Alison Jaggar yang mengamati pemikiran politis liberal atas konsepsinya terhadap kapasitas bernalar yang menjadi keunikan manusia. Awalnya, kerja produktif yang dihasilkan nalar baik laki-laki maupun perempuan dapat diaktualisasikan di lingkungan sekitar tempat tinggal. Perkembangan selanjutnya budaya kapitalisme industri mulai mempengaruhi ruang kerja publik 
sehingga menjadikan tempat bagi tenaga kerja untuk bekerja keluar rumah (Rosemarie, 2004: 15).

Penelitian ini berfokus pada perjuangan Kartini dalam cerita novel biografi Panggil Aku Kartini Saja karya Pram. Oleh karena penelitian ini bukan merupakan kajian ilmu sastra, melainkan ilmu komunikasi maka gaya penulisan tidak akan menjadi pokok bahasan dalam penelitian ini.

Ada beberapa penelitian yang telah dikerjakan dengan menggunakan analisis Naratif Vladimir Propp, diantaranya Mauli \& Badruzzaman (2020) yang menganalisis film "Surat dari Praha". Riset mereka bertujuan mencari tahu perjuangan seorang wanita muda untuk menyerahkan kotak surat dan memperoleh tanda tangan seorang tua yang berada di Praha. Penelitian lain dilakukan Yono (2020) yang berjudul "Struktur Naratif Vladimir Propp dalam Cerita Rakyat Kabupaten Brebes Jaka Poleng”. Dalam penelitian ini, Yono mendeskripsikan fungsi naratif dan lingkungan tindakan dengan menggunakan struktur naratif Propp. Penelitian lainnya (Putri \& Parnaningroem, 2018) yang merupakan penelitian dalam bidang Studi Sastra Jerman. Penelitian ini juga berusaha mendeskripsikan fungsi naratif yang terdapat dalam dongeng tersebut, dan mendeskripsikan lingkungan tindakannya.

Dibandingkan penelitian tersebut, penelitian ini berbeda. Ini terutama karena perspektif feminisme yang digunakan dalam penelitian ini. Dalam hal ini, peneliti bukan hanya ingin mendeskripsikan fungsi naratif dan lingkungan tindakan yang teradapat dalam novel PAKS, tapi juga melihat liniearitas alur yang terdapat dalam novel tersebut dari fungsi naratif dan lingkungan tindakan lewat narasi-anarasi feminisme.

\section{METODE}

Paradigma konstruktivis dipilih sebagai pondasi berpijak penelitian ini. Konstruktivisme menganggap bahwa pengetahuan merupakan hasil dari bentukan manusia itu sendiri (Fernando et al., 2020). Manusia dianggap mengkontsruksi pengetahuan melalui interaksi dengan objek, fenomena, pengalaman, dan juga lingkungan (Rangkuti, 2014).

Penelitian ini bersifat deskriptif kualitatif. Penelitian berusaha menggambarkan, meringankan berbagai kondisi, situasi, serta berbagai fenomena realitas sosial yang ada di masyarakat. Adapun objek dalam penelitian ini, yakni novel biografi Panggil Aku Kartini Saja karya Pram, terdiri atas 262 halaman yang diterbitkan oleh Lentera Dipantara.

Metode penelitian yang digunakan berdasar pada pendekatan penelitian kualitatif (Eveline et al., 2020). Penelitian jenis ini berangkat dari masalah sosial atau menerjemahkan nilai kemanusiaan sehingga kualitatif berusaha untuk mengeksplorasi makna (Ardiani, 2019: 6). Para peneliti kualitatif berusaha melakukan konstruksi pada realitas sosial yang terbangun secara sosial, relasi antara peneliti dengan subjek riset, dan situasi yang terjadi dalam proses penelusuran dilakukan (Fernando et al., 2019). Hal tersebut ditujukan guna menggali jawaban dan memusatkan perhatian terciptanya pengalaman sosial, serta makna yang terkandung di dalamnya (Januarti \& Wempi, 2019: 76).

Teknik pengumpulan data yang digunakan adalah studi literatur sebagai upaya strategis peneliti guna menyimak serta mencatat secara cermat data primer, yakni novel biografi Panggil Aku Kartini Saja karya Pram. Selanjutnya, data yang terkumpul dalam penelitian ini dianalisis dengan menggunakan analisis naratif 
model Vladimir Propp. Model ini digunakan karena memiliki kemampuan dalam memahami identitas dan pandangan dunia seseorang melalui cerita-cerita (narasi) yang didengarkan. Identitas adalah suatu lambang yang patut dipahami oleh pelaku komunikasi (Marta, 2017:1). Selain itu, sebuah teks yang bersifat naratif biasanya meliputi peristiwa yang dipilih, disusun, dihubungkan, dan dievaluasi sehingga bermakna untuk audensi tertentu (Budiwiyanto, 2015: 186).

Propp memerlakukan berbagai karakter berperan strategis dalam sebuah produk narasi. Setiap karakter menempati fungsi guna menggerakkan potongan cerita atas bagian dari pembentuk suatu alur narasi sehingga rangkaian utuh narasi terjalin (Eriyanto, 2013: 66). Oleh Propp, fungsi dipahami sebagai bentuk tindakan dari karakter tertentu, kemudian didefinisikan dari perspektif signifikansinya sebagai tindakan dalam teks. Propp membagi tindakan tersebut menjadi dua aspek utama. Aspek pertama meliputi tindakan yang dilakukan oleh karakter dalam sebuah alur narasi yang pasti saling berbeda sehingga saling membentuk makna. Aspek kedua meliputi konsekuensi dari tindakan karakter yang direfleksikan dalam narasi tersebut. Adapun tindakan yang diciptakan akan saling memengaruhi karakter yang satu dengan lainnya. Dalam operasionalnya, fungsi pelaku juga diberi nomor, hakikat fungsi, definisi dalam satu kata, lambang, dan contoh variasi tindakan guna mempermudah dalam mengemas kerangka dan juga pergerakan dalam cerita (Budiarti, 2012:167).

Struktur naratif Propp (Darajat \& Badruzzaman, 2020: 44) terdiri dari 31 fungsi yang diwakili simbol tertentu, antara lain sebagai berikut: ( $\alpha$ ) Situasi awal; $(\beta)$ Ketidakhadiran atau absensi; $(\gamma)$
Pelarangan; $\quad(\delta) \quad$ Kekerasan; $\quad(\varepsilon)$

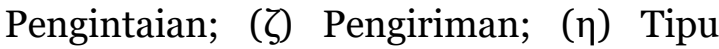
daya; $(\theta)$ Keterlibatan; (A) Penjahat serta (a) Pengincar sesuatu; (B) Mediasi; (C) Tindakan balasan; ( $\uparrow$ ) Keberangkatan; (D) Fungsi seorang penolong; (E) Reaksi dari Pahlawan; (F) Resep dari dukun atau paranormal; (G) Pemindahan Ruang; (H) Perjuangan; (J) Cap; (I) Kemenangan; (K) Pembubaran; (I) Kembali; (Pr) Pengejaran; (Rs) Penyelematan; (O) Kedatangan tidak dikenal; (L) Tidak bisa Mengklaim; (M) Tugas berat; (N) Solusi; (R) Pengenalan; (Ex) Pemaparan; (T) Perubahan rupa; (U) Hukuman; dan (W) Pernikahan.

\section{HASIL DAN PEMBAHASAN}

Berdasarkan hasil penelitian, penggunaan simbol, fungsi, dan juga plot yang sudah dijelaskan oleh Propp dapat dijelaskan bahwa dalam novel biografi sosok Kartini karya Pram mempunyai tujuh fungsi narasi. Tujuh fungsi narasi tersebut diambil oleh peneliti karena narasi yang terdapat pada novel biografi ini bukan merupakan dongeng seperti pada umumnya analisis ini digunakan, tetapi beberapa fungsi dapat diaplikasikan dan menjadi relevan karena narasi ini juga mengandung unsur-unsur seni bercerita seperti berbagai elemen naratif Propp. Ketujuh fungsi narasi yang diperoleh oleh peneliti antara lain: Situasi awal (a); Kejahatan atau kekurangan (A); Tindakan pertama penolong (D); Cap (J); dan Kemenangan (I).

Situasi awal (a) digambarkan terjadinya penggolongan ras. (Utami, 2018) menyebutkan ras sebagai suatu ciri khas yang nampak pada sekelompok orang karena aspek genetik yang dibawanya. Aspek ini umumnya akan nampak secara fisik melalui bentuk tubuh, warna kulit, warna rambut dan lain sebagainya (Ibrahim \& A.S., 2013:2). Kedudukan 
pekerjaan dan jabatan orang tua dalam susunan kepegawaian dan strata sosial pada saat masa sekolah Kartini juga berpengaruh terhadap kehidupannya. Ini terjadi karena adat-istiadat yang berlaku di tanah Jawa serta adanya campur tangan Belanda.

Kejahatan atau kekurangan (A) ditujukan pada sosok ayah Kartini. Ia adalah seseorang yang paling dicintai Kartini karena memahami dan mendukung cita-cita serta gagasan Kartini kecil, tapi hal tersebut belum mampu mengubah cara pandang sang ayah tentang adat-istiadat Jawa dalam memerlakukan seorang wanita. Salah satunya adalah budaya pingitan yang pada akhirnya menjadi titik dimulainya pemikiran-pemikiran Kartini tentang penderitaan kaum wanita.

Tindakan pertama penolong (D) diperankan oleh Estelle Zeehandelaar dan Nyonya Abendanon. Keduanya merupakan sahabat pena Kartini yang sering berbalas-balasan surat dan bertukar pemikiran pada 1899. Kartini menganggap orang- orang Eropa khususnya Belanda merupakan orang yang berjiwa merdeka yang dapat bergaul dengan siapa saja yang menganggapnya bukan hamba, dan menanggapinya sederajat, dan dengan penghargaan. Ini tidak dapat diperoleh Kartini dari bangsanya yang menghamba pada feodalisme. Resep dari dukun atau paranormal (E) merupakan representasi dari cita-cita Kartini sebagai seorang pengarang terinspirasi oleh pamannya, seorang pengarang yang telah mashyur, yaitu Pangeran Ario Hadiningrat, Bupati Demak. Keluarga jauhnya, R.M.A.A. Tjondronegoro, Bupati Kudus, juga merupakan penulis terkenal di Nederland "langsung mendidik" tetapi dalam "lingkungan terbatas" saja, demikian halnya sebagai dokter atau juru rawat, daerah juangnya pun terbatas.
Cap $(\mathrm{J})$ yang dimaksudkan peneliti adalah sudut pandang Indonesia yang bangga memiliki Kartini, yang biasanya hanya dilihat dari segi emansipasi wanita. Namun, lebih dari kitu. Ia dipandang telah mengabadikan peralihan penjajahan Eropa dari taraf kuno ke taraf modern dengan segala segi dan akibatnya. Ia mendasari kehidupan dengan cara baru untuk menggerakkan kekuatan moral yang bersumber dari kecintaan pada sesama manusia sebagai sebuah kewajiban mengabdi negeri, bangsa, dan rakyatnya. Selain itu, Kartini juga dipandang mampu menjadi sosok inspirasi bagi Bangsa Indonesia menempuh jalan menuju kemerdekaan yang sesungguhnya di kemudian hari.

Kemenangan (I) meliputi suratsurat Kartini yang dirangkum menjadi satu oleh Mr. J.H. Abendanon dengan judul Door Deuisternis tot Licht, yang dalam bahasa Indonesia dikenal dengan judul Habis Gelap Terbitlah Terang. Kata pengantar buku itu menjelaskan bahwa penerbitan dimaksudkan sebagai "sumbangan bagi perwujudan apa yang diperjuangkan Kartini”. Selain di Indonesia, dampak pemikiran Kartini juga membantu bagi bangkitnya emansipasi wanita di Syria.

\section{Analisis Fungsi Narasi}

Berdasarkan analisis terhadap fungsi narasi novel biografi Kartini karya Pram, peneliti menemukan bahwa ketujuh fungsi narasi tersebut dapat dikerucutkan lagi menjadi tiga jenis fungsi narasi yang diurutkan berdasarkan alurnya yakni (I) Fungsi narasi represif; (II) Fungsi narasi kontributif; dan (III) Fungsi narasi inspiratif.

Analisis fungsi narasi represif. Analisis fungsi narasi represif, terdiri dari situasi awal (a) dan kejahatan atau 
kekurangan (A), dimana represif menggambarkan tentang sesuatu yang menekan. Situasi awal ( $\alpha$ ) dan kejahatan atau kekurangan (A) merupakan masa dimana Kartini merasa tersiksa dan jiwanya dikekang oleh diskriminasi ras dan kelas yang ia alami di sekolah. Ia juga merasa tersiksa karena budaya Pingitan yang harus dijalaninya sebagai akibat adat-istiadat yang masih kental berlaku di keluarganya, terutama karena ayahnya merupakan seorang Bupati Jepara.

Analisis fungsi narasi kontributif. Analisis fungsi narasi kontributif, yang merupakan fungsi narasi yang diartikan sebagai sumbangsih atau peran dalam kegiatan tertentu yang bersifat membangun atau positif. Dalam fungsi naratif kontributif, dua fungsi narasi yang termasuk di dalamnya adalah fungsi narasi fungsi pertama seorang penolong (D) dan resep dari dukun atau paranormal (role model) yang dilambangkan dengan (F). Kedua fungsi narasi tersebut termasuk dalam fungsi narasi kontributif karena keduanya merupakan peristiwa yang melibatkan peran orang-orang di sekitar Kartini dalam membentuk pemikirannya dengan cara berbalas surat dengan Stella Zeehandelaar dan Nyonya Abendanon, serta Mr. J. H. Abendanon yang ikut berkontibusi dalam mengumpulkan suratsurat Kartini. Tidak hanya itu, proses Kartini terinspirasi oleh paman dan juga saudara jauhnya juga merupakan kontribusi yang diberikan orang lain terhadap pola pikir dan kepribadian Kartini sehingga Kartini berani untuk bermimpi menjadi seorang penulis. Keduanya merupakan fungsi narasi yang memberikan kontribusi dalam hidup Kartini.

Analisis fungsi narasi inspiratif. Analisis fungsi naratif inspiratif terdiri dari tiga fungsi narasi, yakni perjuangan $(\mathrm{H})$, cap (J), dan kemenangan (I). Ketiga fungsi tersebut merupakan bagian dari analisis fungsi narasi inspiratif karena narasi perjuangan, cap, dan juga kemenangan bersifat inspiratif atau dapat menginspirasi orang lain. Mulai dari perjuangan yang Kartini lakukan melalui menulis, cap yang dia dapatkan karena tulisan-tulisan hebat yang berisi tentang pemikirannya, dan juga kemenangan yang merupakan hal yang diperoleh oleh Kartini karena perjuangannya melalui menulis yang dia lakukan semasa hidupnya.

\section{Analisis Karakter Utama}

Dalam novel biografi Panggil Aku Kartini Saja karya Pramoedya Ananta Toer, terdapat tujuh tokoh yang berperan penting dalam analisis fungsi narasi Propp. Ketujuh tokoh dan penokohan tersebut antara lain: (a) Raden Ajeng Kartini; (b) R.M Adipati Sosroningrat; (c) Estelle Zeehandelaar; (d) Mr. J.H Abendanon; (e) Nyonya Abendanon, dan (f) Pangeran Ario Hadiningrat, dan (g) R.M.A.A. Tjondronegoro.

Raden Ajeng Kartini merupakan tokoh dan topik utama yang dibahas pada novel biografi Panggil Aku Kartini Saja. Semasa hidupnya, Kartini dianggap sebagai perempuan Jawa yang memiliki pemikiran maju, tapi terkekang oleh adatistiadat yang masih kuat. Hal itu membatasi Kartini dalam mencapai mimpinya untuk merdeka. Menulis merupakan senjata yang ia gunakan untuk mencurahkan dan melampiaskan perasaan dan isi hatinya. Bertukar pikiran melalui surat-menyurat dengan sahabat Belandanya membuat pikiran Kartini semakin terbuka dan maju. Hingga akhirnya, surat-surat tersebut dirangkum dan dijadikan satu menjadi buku. Pada 2 Mei 1964, melalui Keputusan Presiden Republik Indonesia No. 108 Tahun 1964, Soekarno menetapkan R.A Kartini sebagai Pahlawan Kemerdekaan Nasional, 
sekaligus menetapkan tanggal 21 April, hari lahir Kartini, sebagai Hari Kartini.

\section{R.M Adipati Sosroningrat} merupakan salah satu putra Pangeran Ario Tjondronegoro IV, yang merupakan Bupati Demak dan juga Gusti Kanjeng Ratu Ayu, yang lahir pada 1850 di Jepara. Sosroningrat merupakan Ayah dari Raden Ajeng Kartini yang memiliki dua orang istri, yakni Mas Ayu Ngasirah dan Raden Ajeng Woerjan. Kartini lahir dari Ngasirah pada 28 Raibul tahun Jawa 1808 bertepatan dengan 21 April 1879. Meski tidak terlahir dari ibu yang bergelar bangsawan, Kartini berhak menyandang gelar Raden Ayu setelah memasuki masa pubertas dan menjalani Budaya Pingitan dalam keraton hingga dilamar oleh Raden Adipati Joyodiningrat sebagai suaminya (Putri \& Nurhajati, 2020: 44).

Estelle Zeehandelaar (Stella) dan Kartini adalah sahabat pena, dan mereka sering bertukar surat untuk mengutarakan pemikirannya. Stella merupakan salah satu sahabatnya yang banyak menyumbangkan pemikiran-pemikiran mengenai kebebasan hidup dan emansipasi. Selama mereka bersahabat, Stella sering kali mengirimkan buku bacaan kepada Kartini.

Mr. J.H Abendanon merupakan seorang yang berjasa untuk Kartini karena mengumpulkan surat-surat yang pernah dikirimkan oleh Kartini dan kemudian membukukannya. Buku yang berujudul Door Duisternich tot Licht atau yang berarti Habis Gelap Terbitlah Terang ini diterbitkan pada 1911. Mr. Abendanon wafat pada 13 Desember 1925 di Monako. Nyonya Abendanon atau nama lengkapnya adalah Rosa Abendanon-Mandri merupakan istri dari Mr. J.H Abendanon. Nyonya Abendanon merupakan orang Belanda yang menjadi sahabat Kartini dalam berkirim surat. Peran pasangan Abendanon dalam hidup Kartini sangat besar, mulai dari membentuk pemikirannya sampai dengan mengumpulkan serta membukukan suratsurat Kartini.

Pangeran Ario Hadiningrat bertindak sebagai paman Kartini yang menginspirasi Kartini untuk menulis. Ia pernah menulis Nota berjudul, Sebabsebab Kemunduran Prestise Amtenar Pribumi Serta Bagaimana Jalan untuk Meningkatkannya Kembali. Beberapa bagian dari nota ini pernah diterbitkan oleh Tijdschrift v/b Binnenlandsch Bestuur Jilid XVII, 1899. Selain sosok Pangeran Ario Hadiningrat yang menjadi tokoh inspirator, Raden Mas Adipati Ario Tjondronegoro juga merupakan paman Kartini yang menginspirasinya dalam menulis.

\section{Analisis Fungsi Karakter}

Berdasarkan analisis yang
dilakukan peneliti terhadap fungsi karakter yang terdapat dalam novel biografi Panggil Aku Kartini Saja karya Pramoedya Ananta Toer, ditemukan bahwa keempat karakter yang terdapat dalam narasi tersebut dapat dikerucutkan menjadi tiga fungsi karakter yang sejalan dengan fungsi narasi yang sudah disebutkan pada analisis fungsi narasi sebelumnya. Fungsi karakter yang diperoleh juga diurutkan berdasarkan alurnya: (I) fungsi karakter represif; (II) fungsi karakter kontributif; dan (III) fungsi karakter inspiratif.

Analisis fungsi karakter represif. Fungsi karakter represif dalam narasi ini adalah ayah Kartini, yakni R. M Adipati Ario Sosroningrat yang memiliki karakter penjahat. Sesuai dengan fungsinya dan apa yang dilakukan oleh ayah Kartini terhadap Kartini, apa yang dilakukan oleh Sosroningrat terhadap Kartini merupakan tindakan represif yang menekan Kartini 
dengan budaya Pingitan yang diberlakukan ayahnya terhadap Kartini.

Analisis fungsi karakter kontributif. Fungsi karakter kontributif terdiri dari dua karakter, yakni penolong dan juga donor. Penolong terdiri dari Nyonya Abendanon, Estella

Zeehandelaar, dan Mr. J.H Abendanon. Donor terdiri dari Pangeran Ario Hadiningrat (paman Kartini) dan R. M. A. A Tjondronegoro (keluarga jauh Kartini). Apa yang dilakukan oleh penolong dan juga donor merupakan tindakan kontributif yang dilakukan semasa Kartini berjuang dalam hidupnya.

Analisis fungsi karakter inspiratif. Termasuk dalam fungsi karakter inspiratif adalah pahlawan, dalam hal ini adalah Kartini itu sendiri. Tindakan Kartini sebagai pahlawan termasuk tindakan yang menginspirasi untuk hidup Kartini sendiri ataupun untuk hidup orang lain. Perjuangan yang Kartini lakukan memberi dampak bagi perempuan-perempuan bahkan dari belahan dunia lain sehingga perjuangan yang dilakukan oleh Kartini dapat digolongkan dalam fungsi karakter inspiratif.

\section{Fungsi Karakter dalam Narasi}

Analisis atas novel biografi Panggil Aku Kartini Saja menemukan pula fungsi narasi dan karakter seperti yang sudah disebutkan oleh Vladimir Propp. Analisis tersebut berfungsi dalam membantu melihat pembentukan serta penggambaran karakter. Fungsi-fungsi yang terdapat dalam narasi berita tersebut dapat dikatakan sebagai struktur luar dari narasi. Dari struktur narasi tersebut, muncul fungsi narasi dan karakter selama Kartini hidup.

Berdasarkan analisis yang sudah dilakukan oleh peneliti, Situasi Awal (a) menjelaskan peristiwa yang dialami oleh
Kartini kecil, dimana peristiwa tersebut berkaitan dengan ketidakadilan yang diterima oleh Kartini. Peristiwa yang ia alami tersebut menjadi titik awal dimana Kartini melihat diskriminasi ras ataupun gender yang terjadi di tanah Jepara. Melalui situasi tersebut pula, sepanjang proses hidupnya, ia menyadari bahwa hal itu juga terjadi karena penjajahan Belanda terhadap kaum pribumi, serta adatistiadat Jawa yang harus diterapkan dalam kehidupannya. Ini terutama karena ia berasal dari keluarga bupati. Seorang bupati ataupun keluarganya harus menjadi contoh bagi masyarakat yang dipimpinnya. Salah satunya adalah dengan tetap melestarikan dan hidup dalam adat-istiadat Jawa.

Pada fungsi narasi kejahatan atau kekuarangan (A), ayah Kartini, R. M Adipati Ario Sosroningrat, merupakan tokoh yang digambarkan sebagai penjahat. Kejahatan yang diterima oleh Kartini berupa diskriminasi, ketidakdalian, ketimpangan gender ataupun ras (Felim et al., 2018). Ayah Kartini merupakan seorang yang selama hidup Kartini menerapkan budaya pingitan. Budaya pingitan merupakan salah satu contoh adat-istiadat Jawa yang membatasi hakhak perempuan dalam menjalani hidupnya. Kartini mengalami keterbatasan dalam melakukan tindakan ataupun menyampaikan pendapat. Selama masa pingitan itu pula, Kartini merasakan duka yang mendalam karena ia merasa hidupnya dibatasi oleh adat-istiadat melalui ayahnya sendiri. Penderitaan yang ia alami tidak menghalangi rasa cintanya terhadap ayah yang sangat ia kagumi.

Fungsi selanjutnya adalah tindakan pertama penolong (D) yang digambarkan dalam tindakan Estelle Zeehandelaar dan Nyonya Abendanon.

Dalam fungsi narasi ini pula, Stella dan Nyonya Abendanon digambarkan 
sebagai sosok penolong karena sepanjang hidup Kartini yang dibatasi oleh budaya pingitan, Stella dan Nyonya Abendanon telah menjadi sahabat Kartini, tempat Kartini mencurahkan beragam perasaan dan pemikirannya melalui surat-surat yang saling mereka kirimkan. Tidak hanya itu, Stella dan Nyonya Abendanon juga membuka dan turut menyumbang pemikiran- pemikiran hebat Kartini tentang konsep kemerdekaan dan kebebasan. Lebih dari itu, peran Stella dan Nyonya Abendanon sebagai penolong juga terlihat jelas karena selama masa pingitannya, tidak banyak hal yang dapat dilakukan oleh Kartini untuk memperjuangkan hidupnya ataupun memperjuangkan hak-hak hidup untuk rakyatnya kecuali melalui tulisan.

Stella dan Nyonya Abendanon hadir sebagai penolong dengan menjadi sahabat pena bagi Kartini. Ini juga merupakan tindakan yang mendukung perjuangan Kartini yang hanya dapat ia lakukan dengan menulis. Resep dari dukun atau paranormal (E) yang dimaksudkan pada novel biografi ini adalah insiprasi yang diperoleh Kartini dalam bercita-cita menjadi seorang penulis. Cita-cita tersebut ternyata tidak semata-mata ia peroleh dengan sendirinya, dan bukan hanya karena tuntutan perjuangan, tapi paman dan saudara jauh Kartini telah terlebih dahulu memberikan contoh konkrit kepada Kartini. Ini membangkitkan dan memacu semangat Kartini sehingga dalam analisis ini Pangeran Ario Hadiningrat (paman Kartini) dan R. M. A. A. Tjondronegoro (saudara jauh Kartini) ditempatkan sebagai donor.

Fungsi narasi yang selanjutnya adalah perjuangan $(\mathrm{H})$. Dalam fungsi narasi ini, yang dimaksudkan ke dalam bentuk perjuangan Kartini adalah menulis. Kartini memilih untuk berjuang dengan sastra. Hal tersebut dilakukannya karena menjadi satu-satunya bentuk perjuangan yang dapat dilakukannya selama ia berada dalam masa pingitan. Selain itu, Kartini juga merasa bahwa melalui menulis dapat memudahkan perjuangannya karena sastra mempunyai daerah jangkauan yang lebih luas. Dalam hal ini, Pram menampilkan Kartini sebagai tokoh atau sosok pahlawan yang berjuang melalui tulisan. Novel itu juga menggambarkan bahwa menulis telah menjadi bagian hidup karena keluarga Kartini banyak yang menekuni bidang sastra sehingga cita-cita sekaligus perjuangannya tersebut sudah tertanam sejak dini dalam diri Kartini.

Cap (J) merupakan fungsi narasi yang menjelaskan bahwa nama Kartini sudah mulai dikenal oleh orang banyak. Ia mulai dikenal karena perjuangan yang sudah dilakukannya, yakni menulis. Kartini dikenal dengan pemikirannya yang maju dibandingkan dengan perempuanperempuan pada zamannya melalui tulisan- tulisannya. Kartini juga dinilai sebagai perempuan yang tidak hanya memikirkan kebebasannya tapi juga rakyat- rakyatnya. Nama Kartini mulai terdengar sebagai perempuan yang mengabadikan peralihan penjajahan dari taraf yang kuno ke modern, meskipun bukan melalui perjuangan dalam bentuk fisik, tapi dalam bentuk tulisan.

Fungsi narasi yang terakhir adalah kemenangan (I). Kemenangan yang diraih Kartini atas hasil perjuangannya, yakni terciptanya buku yang berjudul Door Deuisternis tot Licht atau yang dikenal dengan Habis Gelap Terbitlah Terang yang berisi rangkaian surat-surat Kartini semasa hidupnya. Melalui buku ini, karyakarya dan pemikiran-pemikiran Kartini semakin dikenal oleh banyak orang dan semakin banyak juga orang-orang yang mengagumi pemikiran dan tulisannya.

Door Deuisternis tot Licht diterjemahakan ke dalam berbagai macam bahasa. Tidak hanya tulisan dan juga pemikirannya, semangat Kartini juga turut 
membangkitkan semangat juang wanitawanita dari negara lain yang kebebasan serta kemerdekaannya masih dijajah oleh banyak hal. Tulisan, pemikiran, dan semangat Kartini membawa perubahan terutama bagi para wanita untuk berani dalam memperjuangkan hak, kebebasan, dan kemerdekaan hidup.

Serangkaian proses penelitian yang dilakukan baik melalui fungsi narasi, karakter utama, fungsi karakter hingga fungsi karakter dalam narasi, dihasilkan model temuan berdasarkan analisis naratif Propp yang menyatakan bahwa terdapat linearitas alur pada narasi dan juga karakter. Linearitas alur pada narasi dan karakter tersebut juga berdasarkan pada urutan peristiwa yang tertulis dalam novel biografi Sosok Kartini karya Pram. Alur pada narasi ataupun karakter ini berbentuk linear karena memiliki urutan yang sama baik secara sifat maupun alurnya dengan urutan represif, kontributif, dan juga inspiratif.

\section{Isi Perjuangan Dilihat dari Feminisme}

Dalam penelitian ini, peneliti menggunakan teori feminisme sebagai acuan pemilihan narasi yang kemudian digabungkan menjadi satu ke dalam plot yang digunakan dalam menganalisis fungsi narasi. Terdapat 15 narasi yang sudah dipilih berdasarkan unsur feminisme yang terdapat dalam narasi-narasi tersebut.

Dilihat dari narasi-narasi tersebut, dapat diketahui bahwa isi perjuangan Kartini dalam membela emansipasi wanita berawal dari tindakannya ketika menyadari adanya ketimpangan peran gender dalam lingkungan keluarganya. Selain itu, perjuangan Kartini dalam membela emansipasi wanita terlihat dalam upayanya menuangkan pemikiranpemikirannya dalam surat-surat yang ia tuliskan kepada sahabat-sahabat Belandanya.

Isi perjuangan Kartini juga terwujud dalam keberaniannya untuk bercita-cita sebagai seorang penulis dan mewujudkan mimpinya tersebut dengan mencurahkan perasaan dan pemikirannya ke dalam tulisan, tidak seperti pahlawan pada umumnya yang berjuang dengan berperang dengan menggunakan senjata. Senjata Kartini sendiri adalah pemikirannya dan juga pena yang ia gunakan untuk memperjuangakan kaum perempuan pada masa itu dengan kekuatan moralnya.

Berdasarkan hasil penelitian yang sudah dilakukan oleh peneliti, dihasilkan model temuan berdasarkan analisis naratif Propp yang menyatakn bahwa terdapat kesamaan alur pada narasi dan juga karakter. Kesamaan alur pada narasi dan karakter tersebut juga berdasarkan pada urutan peristiwa yang tertulsi dalam novel biografi Panggil Aku Kartini Saja karya Pramoedya Ananta Toer. Kesamaan alur pada narasi dan karakter ini berbentuk linear karena memiliki urutan yang sama baik secara sifat maupun alurnya, dengan urutan represif, kontributif dan juga inspiratif.

\section{KESIMPULAN}

Berdasarkan hasil dan pembahasan yang sudah dijelaskan, dapat ditarik dua kesimpulan. Pertama, terdapat tujuh dari 31 fungsi narasi dan juga tujuh karakter yang dikelompokkan ke dalam empat fungsi karakter. Ketujuh fungsi narasi tersebut antara lain situasi awal ( $\alpha$ ), kejahatan atau kekurangan (A), fungsi pertama seorang penolong (D), resep dari dukun atau paranormal (F), perjuangan $(\mathrm{H})$, cap (J), kemenangan (I). Keempat fungsi karakter yang diperoleh adalah penjahat (R. M. Adipati Ario Sosroningrat), penolong (Mr. J.H. 
Abendanon, Nyonya Abendanon, Estelle Zeehandelaar), donor (Pangeran Ario Hadiningrat dan R. M. A. A Tjondronegoro), dan pahlawan (R. A Kartini). Fungsi narasi dan fungsi karakter juga sejalan dan sesuai sehingga menghasilkan fungsi naratif yang linear atau sejajar, yakni fungsi naratif represif, kontributif.

Kesimpulan yang kedua bahwa melalui fungsi naratif dan juga fungsi karakter yang sudah diperoleh, didapatkan bahwa semangat Kartini dalam memperjuangkan emansipasi melalui tulisan dan juga pemikirannya yang sudah terangkum dalam novel biografi Panggil Aku Kartini Saja harus selalu dihidupi dalam kegiatan sehari-hari. Ini karena berkat perjuangannya perempuan Indonesia sudah dapat menikmati kehidupan yang layak terutama dalam kehidupan bermasyarakat

Novel biografi Panggil Aku Kartini Saja karya Pramoedya Ananta Toer memiliki tujuh dari 31 fungsi naratif yang dinyatakan oleh Propp, diantaranya adalah situasi awal yang dimulai ketika Kartini memasuki masa sekolah, kejahatan atau kekuarangan yang dinyatakan dalam peristiwa diterapkannya budaya pingitan kepada Kartini yang dilakukan oleh ayahnya. Fungsi pertama penolong (D) yakni pada saat Kartini mengenal Estelle Zeehandelaar dan juga Nyonya Abendanon yang akhirnya menjadi sahabat-sahabat Kartini dalam, resep dari dukun atau paranormal (E) pada saat Kartini mulai terinspirasi dari paman dan saudara jauhnya, yaitu Pangeran Ario Hadiningrat dan juga R. M. A. A Tjondronegoro. Perjuangan $(\mathrm{H})$ adalah ketika Kartini memilih sastra sebagai alat perjuangannya, cap (J) ketika nama dan juga pemikiran Kartini mulai dikenal oleh orang banyak lewat tulisannya, kemenangan (I) saat surat- surat Kartini berhasil dibukukan dan diterbitkan sebagai dukungan dan bukti dari perjuangan Kartini, serta semangat juangnya dirasakan di berbagai belahan dunia.

Kemudian ke-31 fungsi narasi tersebut dikelompokkan lagi ke dalam tiga alur fungsi narasi yang secara berurutan terdiri dari represif, kontributif, dan inspiratif. Alur ini dimulai dari kondisi represif, yaitu berkenaan dengan sesuatu yang menekan, di dalamnya terdapat situasi awal a dan kejahatan atau kekurangan (A). Dilanjutkan dengan kontributif tentang sesuatu yang bersifat keterlibatan yang membangun, yakni tindakan pertama penolong (D), resep dari dukun atau paranormal (role Model) yang dilambangkan dengan (E), dan juga perjuangan $(\mathrm{H})$. Diakhiri dengan inspiratif, yakni mengenai sesuatu yang bersifat menginspirasi, di dalamnya terdapat fungsi narasi cap $(\mathrm{J})$ dan kemenangan $(\mathrm{H})$ sehingga terjadi liniearitas alur pada novel biografi Panggil Aku Kartini Saja karya Pramoedya Ananta Toer.

Sejalan dengan fungsi narasi yang sudah diperoleh, fungsi karakter yang didapat dari analisis juga diperoleh empat karakter pokok yang dikelompokkan juga menjadi tiga fungsi karakter, yang juga sesuai dengan analisis fungsi narasi berdasarkan fungsi karakter dan juga alur yang sudah ada. Tiga fungsi karakter tersebut adalah represif yang mana penjahat termasuk di dalamnya. Fungsi narasi kontributif, yaitu donor dan penolong. Fungsi narasi inspiratif, yakni pahlawan sehinga terjadi liniearitas alur antara narasi dan juga karakter. 


\section{DAFTAR PUSTAKA}

Aliyah, I. H., Komariah, S., \& Chotim, E. R. (2018). Feminisme Indonesia dalam Lintasan Sejarah. TEMALI : Jurnal Pembangunan Sosial, 1(2), 140-153. https://doi.org/10.15575/jt.v1i2.329 6

Ardiani, S. M. (2019). Panggung Dalang Perempuan Wayang Kulit Purwa: Analisis Gender Atas Nyi Arum Asmarani. Martabat: Jurnal Perempuan Dan Anak, 3(1), 1-22. https://doi.org/10.21274/martabat. 2019.3.1.1-22

Budiarti, E. (2012). Lakon Baratayuda Versi Klaten: Kajian Struktur Naratif. Resital, 13(2), 166-180.

Budiwiyanto, A. (2015). Analisis naratif personal lisan siswa sekolah dasar. Aksara, 27(2), 185-193.

Eriyanto. (2013). Analisis Naratif: Dasardasar Penerapannya dalam Analisis Teks Berita Media. Prenamedia Grup.

Eveline, S., Marta, R., Fernando, J., Rahyadi, I., \& Nur'Aini, S. (2020). Increasing Social Relations Quality by Socioemotional Selectivity of Elderly at PERWAJAS Community. The 4th International Conference of Social Science and Education, 2. https://doi.org/10.4108/eai.4-82020.2302473

Felim, P., Dimyati, D., \& Shihab, M. (2018). ASKfm: Motives of SelfDisclosure to Anonymous Questions. Jurnal Komunikasi, 13(1), 93-108. https://doi.org/10.20885/komunika si.vol13.iss1.art7

Fernando, J., Marta, R. F., \& Hidayati, R. K. (2020). Reaktualisasi mahasiswa diaspora Indonesia dalam menjaga identitas budaya bangsa di Benua Australia. Jurnal Kajian

Komunikasi, 8(2), 194-206. https://doi.org/10.24198/jkk.v8i2.2 5219

Fernando, J., Sya, M., \& Marta, R. F. (2019). Amalgamation as a Strengthening Ethic. MIMBAR : Jurnal Sosial Dan Pembangunan, 35(2), 334-341.

https://doi.org/10.29313/mimbar.v $35 \mathrm{i} 2.4863$

Gumelar, R. G., \& Mukhroman, I. (2015). Tato: Representatif Gender dalam Prespektif Feminisme. Jurnal Kajian Komunikasi, 3(1), 71-80.

Ibrahim, S. M., \& A.S., A. B. (2013). Hambatan Komunikasi Antar Budaya Pada Aspek Ras (Analisis Kritis pada Kasus Indonesia Tionghoa). Bricolage: Jurnal Magister Ilmu Komunikasi, 1, 1-6.

Januarti, \& Wempi, J. A. (2019). Makna tenun ikat dayak sintang ditinjau dari teori semiotika sosial theo van leeuwen. Bricolage: Jurnal Magister Ilmu Komunikasi, 5(1), 73-90.

Marta, R. F. (2017). Esensi Dan Pemetaan Teoretisasi Media Komunikasi Dalam Perspektif Karl Marx. Bricolage: Jurnal Magister Ilmu Komunikasi, 2(02), 117-123. https://doi.org/10.30813/bricolage. v2io2.839

Masofa, I. (2018). Comparative Literature Faulkner's a Rose for Emily and Pramoedya's Panggil Saja Aku Kartini. Dinamika : Jurnal Sastra Dan Budaya, 6(1). https://doi.org/http://dx.doi.org/10 .25139/dinamika.v6i1.1115 
Mauli Darajat, D., \& Badruzzaman, M. (2020). Analisis Fungsi Narasi Model Vladimir Propp dalam Film Surat dari Praha. CoverAge: Journal of Strategic Communication, 10(2), 40-58. https://doi.org/10.35814/coverage.v $10 \mathrm{i} 2.1382$

Mulyadi, U. (2018). Representasi Perempuan Dalam Film Cinta Suci Zahrana. Jurnal Ilmiah Komunikasi Makna, 6(2), 150. https://doi.org/10.30659/jikm.6.2.1 50-158

Mustikawati, C. (2015). Pemahaman Emansipasi Wanita (Studi Hermeneutika Makna Emansipasi Wanita Dalam Pemikiran R. A. Kartini Pada Buku Habis Gelap Terbitlah Terang). Jurnal Kajian Komunikasi, 65(5), 65-70.

Muthoifin, Ali, M., \& Wachidah, N. (2017). Pemikiran raden ajeng kartini tentang pendidikan perempuan dan relevansinya terhadap pendidikan islam. PROFETIKA: Jurnal Studi Islam, 18(1), 36-47.

Novarisa, G. (2019). Dominasi Patriarki Berbentuk Kekerasan Simbolik Terhadap Perempuan Pada Sinetron. Bricolage : Jurnal Magister Ilmu Komunikasi, 5(02), 195. https://doi.org/10.30813/bricolage. v5io2.1888

Omara, A. (2004). Perempuan, Budaya Patriarki dan Representasi. Mimbar Hukum, II(46), 148-165.

Putri, A., \& Nurhajati, L. (2020). Representasi perempuan dalam kukungan tradisi Jawa pada film Kartini karya Hanung Bramantyo Film by Hanung Bramantyo. ProTVF, 4(1), 42-63.

Putri, K. P. I., \& Parnaningroem, D. W. (2018). Struktur Naratif Vladimir Yakovlevich Propp Dalam Dongeng
Die Zertanzten Schuhe Karya Brãœder Grimm. Identitaet, 7(2).

Rahayu, R. I., \& Aprilia, I. R. (2018). Rekonstruksi Pemahaman Kebangsaan: Percakapan Tentang Perempuan dan Kebangsaan. Jurnal Perempuan, 23(3), 183-192.

Rajab, B. (2018). Representasi Perempuan dalam Lembaga Politik di Indonesia. Jurnal Masyarakat Dan Budaya, 2O(2), 211-222.

Rangkuti, A. N. (2014). Konstruktivisme dan Pembelajaran Matematika. Darul Ilmi, 2(2), 61-76. http://jurnal.iainpadangsidimpuan.ac.id/index.php/ DI/article/view/416

Rosemarie, P. T. (2004). Feminist Thought: Pengantar Paling Komprehensif Kepada Aliran Utama Pemikiran Feminis. Jalsutra.

Sakina, A. I., \& Siti, D. H. (2017). Menyoroti budaya patriarki di indonesia. SHARE: SOCIAL WORK JURNAL, 7(1), 71-80.

Sari, R. P. (2014). Pembungkaman Kaum Perempuan Dalam Film Indonesia (Penerapan Teori Muted Group Dalam Film "Pertaruhan"). Jurnal Komunikasi, 9(1), 117-125. https://doi.org/10.20885/komunika si.vol9.iss1.art9

Septiani, A. (2017). Implementasi NilaiNilai Perjuangan Kaum Perempuan Dalam Surat Kabar Poetri Hindia 1908-1911. Jurnal Candrasangkala Pendidikan Sejarah, 3(1), 43. https://doi.org/10.30870/candrasa ngkala.v3i1.2887

Sumar, W. T. (2015). Ilmplementasi Kesetaraan Gender dalam Bidang Pendidikan. Musawa, o7(1), 158182. https://doi.org/10.1016/j.anuro.200 3.10.003 
Utami, P. N. (2018). Pencegahan Kekerasan Terhadap Anak dalam Perspektif Hak Atas Rasa Aman Di Nusa Tenggara Barat. Jurnal HAM, 9(1), 1.

https://doi.org/10.30641/ham.2018 .9.1-17

Yono, R. R. (2020). Struktur Naratif Vladimir Propp dalam Cerita Rakyat Kabupaten Brebes "Jaka Poleng." Syntax Literate : Jurnal Ilmiah Indonesia, 5(2), 100-111. https://doi.org/10.1088/17518113/44/8/085201
You, Y., Rusmansara, E. H., Mansoben, J., \& Poli, A. I. (2019). Relasi Gender Patriarki Dan Dampaknya Terhadap Perempuan Hubula Suku Dani, Kabupaten Jayawijaya, Papua. Sosiohumaniora, 21(1), 65. https://doi.org/10.24198/sosiohum aniora.v21i1.19335 